\title{
Practice of Module Teaching Method on the Clothing Structure Design Course
}

\author{
Meng Xiangling, Liu Kan, Yang Tianqi \\ School of Fashion Design \\ Shanghai Institute of Art \\ Shanghai, China \\ mxldream@163.com
}

\begin{abstract}
In order to train the students' ability to transform the style design into the two-dimensional pattern and to improve students' innovation and practice ability, clothing structure course was as a link in the whole fashion design. The teaching method was named Module Teaching Method. In this method, clothing structure design was be included a module course named Fashion or Clothing Design. This course was no longer isolated. The content of the course was closely related with advanced and later courses. Teachers included in the module prepared lessons collectively and decided the assessment contents and methods of the curriculum, and then confirmed the teaching contents, teaching form and method. According to this study, student can design, pattern and sewing independently. Also students' creative ability can be enhanced in the whole teaching process. This teaching practice is consistent with the real clothing industry production process.
\end{abstract}

Keywords-clothing structure design; module teaching method; student centered education

\section{INTRODUCTION}

Clothing structure design is important for fashion design. A creative clothing design should be realized through pattern design. The purpose of clothing structure course is to train the ability of pattern design. In other words, to train the students' ability to transform the style design into the two-dimensional pattern is the basic requirement of the clothing structure course. And to improve students' innovation and practice ability is the new goal of the clothing structure course.

Clothing structure design is a foundation course for clothing specialty in Chinese colleges and universities. It's normally defined as a required professional and core course.

Traditionally, the course is classified as engineering courses rather than arts courses. However, the students of clothing specialty mainly major in arts in Chinese. As a matter of fact, they are not good at math. Comparing with logical thinking, they are more familiar with imaginal thinking. Most students are not interested in the clothing structure design course.

The students who were majored in fashion design and engineering often engaged in the management or marketing work when they graduated from university. At present, most of pattern designers in garment enterprises graduated from

This paper is supported by the research project of "the application of modular teaching mode of Applied Undergraduate clothing and fashion design" in Shanghai private colleges and universities. The project number is 2016-SHINGE-07ZD. vocational schools or trained by the factory workers.

In most clothing companies, designers were responsible for style design. They can draw fashion style. But many fashion designers can't communicate effectively with the pattern design. That is because fashion designer lacked of clothing structure knowledge and pattern designer lacked of fashion are design. Sometime they couldn't understand each other's purpose.

Most fashion designers were majored in fashion art design. They received a large number of fashion design training. But they lacked of actual pattern making and production capacity.

A good design needs bearing creative thinking. And a good clothing production needs the appropriate structure design. For clothing enterprises and our clothing industry, the talent personnel who have the knowledge of clothing structure design and fashion art style design are urgently needed

Many researchers have studied how to teach clothing structure design in China. Duan's report pointed out advanced courses should be arranged reasonably to stir up students' interest in clothing structure design course [1]. However the report didn't study the essential connection between courses. Zhi's study described establishing the theoretical system for dress structure design course and comprehensive application of modern and traditional teaching methods [2]. The researcher considered that the plane combined together with threedimension can enhance the teaching effectiveness. Qin thought the clothing structure course as a creative activity and emphasized the teaching in practice [3].

In this paper the course of clothing structure design is not isolated. It should be closely connected with relative course in education. The course assessment is also closely connected with advanced and later courses included in the same module.

The teaching method is in line with the garment industry. And the education should cultivate the talents for enterprises.

\section{ANALYSIS OF CLOTHING STRUCTURE DESIGN COURSE}

\section{A. Overview of Clothing Structure Design Course}

Firstly, through clothing structure design 3D clothing style were decomposed into 2D pattern and detail of shapes, amount, matching relationship and master-detail relationship were 
described. The un-decomposable part in the style must be corrected at the same time. The design of waste of effort and materials were amended. On the other hand, a series of patterns with a complete range of specifications and reasonable structure were provided to industry through clothing structure design [4].

Clothing structure design plays an important role in the fashion design. It is a bridge between the preceding and the following. It's fairly necessary in the whole clothing design process.

In theory, clothing structure consists of planar structure and three-dimension structure. The planar structure is also called plane cutting. At present, clothing structure design course often refer to the knowledge of plane cutting in China's colleges and universities. In this paper, the following clothing structure design course is different from the three-dimensional cutting course.

\section{B. Analysis Teaching of Clothing Structure Design Course}

Clothing structure design course is a combination of art and technology courses. Most students majored in fashion design are good at image thinking. The logical thinking and the ability to transform between the three-dimensional and twodimensional are weak.

Therefore, many teachers introduced the three-dimensional method into the course of the plane design in recent years. That is the combination of three-dimensional structure design and graphic design so that students can understand the content of the course better.

In most colleges of China, courses of clothing design are independent. For example, clothing style design, clothing structural design, clothing sewing technology classes, all these courses are taught by different teachers respectively. Therefore, the clothing structure design course is not only the lack of connection with the advanced courses, but also the practical operation of the following courses. As a result, students can not complete the whole process of garment design independently even they have completing these courses

In order to help students majored in fashion design can independently complete the process from fashion design to clothing apparel, clothing structure course should be arranged in a complete fashion design course module to complete.

Specific teaching practice is as follows.

\section{The Teaching Practice of Clothing Structure DESIGN COURSE}

\section{A. Module TeachingMethods}

MES (Modules of Employable Skills) and CBE (Competency Based) are more representative methods of module teaching methods in the world. The module teaching method that is introduced in this paper is mainly based on the module teaching of "wide base, live module" in the educational domain of China. Through the flexible and reasonable collocation among the courses included in modules, the students can complete the whole process of garment design and improve their professional competence.

\section{B. Clothing Design Module}

Firstly, clothing design was defined as a teaching module, which includes three main courses: fashion design, clothing structure design and clothing technology design. At the same time, clothing materials science is also included in the module.

The three main courses of the module are still taught by different professional teachers, but it will no longer be independent. The teachers of the three courses should arrange the process based on completed communication with each other before teaching. A case study on the basis of costume design is as follows.

Three teachers should develop the final class assessment together. For example, the module courses require students to complete the production of one-piece sleeveless dress with no collar independently. Then the teacher of style design can prepare the curriculum knowledge points of the design according to the title of this work. At the end of the class, the students need to submit a certain number of collars-less, sleeveless one-piece dress sketches and selections.

\section{Clothing Structure Design Course in the Module}

The curriculums content of clothing structure design courses were also adjusted and knowledge points were amended based on the requirements of the course module. Female bodice prototype, the prototype dart transfer, prototype pattern expansion (including provincial transfer, creasing production, horn production and so on), segmentation principle, various prototypes without collar type design are taught. After the theory teaching, students were required to choose the clothing style designed in style design course, and to make the pattern for the selected style independent according to the knowledge of clothing structure design course.

Between the clothing structure design course and the clothing making course, the sample sewing and the pattern correction were added. Students can think about the process of clothing making; try to find out the unreasonable structure of the sample, and then make a correction. Through the sewing of sample and pattern correction, students' abilities of thinking, learning and resolving questions were improved. The teaching is in line with the teaching objectives of the clothing structure, and also in line with the actual garment industry.

After the pattern amended, the actual fabric should be selected. Students went to the fabric market to choose the material. They bought the materials under the guidance of teaching; consider the style of design, the cost, the amount and the clothing sewing requirements. At the same time learning determine the fabric.

Finally, Students completed the making of clothes in the clothing technology course.

A large number of studies have proved that students can learn new knowledge effectively if connect the new knowledge with the old knowledge [5].Therefore, the module teaching method built a bridge between the old knowledge and new 
knowledge for students. The module teaching method likes an advanced organizer. It helps students to understand the new knowledge, to promote the transfer of learning, to prevent the broken between old and new knowledge and weaken the effectiveness of learning.

\section{MODERN EDUCATION CONCEPT AND TEACHING IDEA OF MODULE TEACHING METHOD ON CLOTHING STRUCTURE DESIGN COURSE}

\section{A. Modern Education Concept of Module Teaching Method on Clothing Structure Design Course}

The modern education concepts of all-round development, the student based democratic view and the individualized teaching view ere followed in the module teaching of clothing structure design course.

In the modular teaching practice, students were the center and were taught in accordance with their aptitude. Different learning stages, included pattern making, fabric selection, sample sewing, pattern correction, students can got the teachers personalized guidance.

In the guidance, teaching goal changed from the only aiming at teaching the students how to learn the structure design knowledge to stimulate students to create different style pattern design by the basic theory. In the creation, students can show their different personalities to teachers. And they could get the personal guidance. Students were encouraged explore, trial and even make error. At the practice, students' innovative spirit and practical ability were cultivated.

In the modular teaching practice of the clothing structure design, students were not only encouraged innovation, but also have enough practice to deepen the study of the theory teaching. This is consistent with the idea of "learning by doing" by Dewey, J., who was a famous educational reformer in the United States in the early twentieth Century [6].

\section{B. Modern Teaching Idea of Module Teaching Method on Clothing Structure Design Course}

Students were given certain right to design the style they like. Students practice the complete clothing design process in the modular teaching of clothing structure design course. It can help students develop comprehensively.

In traditional course, most of teachers often teach basic theory knowledge in the classroom, draw the clothing structure pattern on the blackboard. And then students take notes and draw clothing structure with scales followed the teacher. Teachers usually explain a variety of styles. It is difficult to reflect the personality by traditional class. The creativity of students cannot be cultivated.

The teachers of the team of module teaching of clothing structure courses use the teaching method, heuristic, discussion, visual presentation, practice in class. And they all follow the theory from teacher centered to student centered.

Modern garment enterprises need the designer with basic theory and creativities who not only can design the style but also master the technology. Traditional teaching method cannot meet the requirement of the talents of our garment enterprises.

The assessment methods of clothing structure design course focus on the ability to apply knowledge, the students' creativity and practical spirit.

\section{Teaching Effectiveness of Module Teaching Method ON CLOThING STRuCTURE DESIGN COURSE}

\section{A. Course Assessment}

The course assessment cancels the traditional examination mode, and no longer uses the form of drawing a given style pattern.

The last works of course of clothing structure design are the style designs, patterns and the final garments. Students were required to make clothing design manual and KT board, which should fully reflect the whole process of learning, creation and practice.

According to the students' work the teacher can clearly see students master the knowledge of clothing structure design deeply. And students can correct pattern and improve making method through practice. Students' innovation ability can be developed. Students gain confidence in learning, thereby enhancing the interest in course and related courses.

\section{B. Course Assessment Feedback}

Students can grasp the change of prototype method in clothing structure design, can design style and pattern independently, and can making garment independently through the course of clothing structure design of module learning methods. They also can better understanding the whole garment design process.

Through the observation of classroom, students can really grasp the principle of making pattern and finish their own design concept. That can stimulate learners' learning selfconfidence. The works of the course were displayed; the students were satisfied with the learning process.

After the text edit has been completed, the paper is ready for the template. Duplicate the template file by using the Save As command, and use the naming convention prescribed by your conference for the name of your paper. In this newly created file, highlight all of the contents and import your prepared text file. You are now ready to style your paper; use the scroll down window on the left of the MS Word Formatting toolbar.

\section{CONCLUSIONS AND FUTURE WORK}

The module teaching method on clothing structure design course has achieved good teaching effectiveness. It is based on the students and to meet the market demand for talent. In practice, the problems needed to be solved are as follows.

First, module teaching methods needs all teachers in the team to communicate and adjust the curriculum content, teaching methods. This requires a long time to run. 
Secondly, in the module teaching, teachers try to combine the market and introduce the project into the course learning. However, knowledge of market are not in the module, therefore, market research requires time, the class had to be compressed. Therefore, the follow-up course construction will take the market courses in to the module to meet the market demand.

Thirdly, there is large proportion of theoretical knowledge in the course of the clothing structure design. Teaching of theoretical knowledge still takes up a large time of the class, although a variety of teaching methods are adopted. The time for students to create and practice has to be compressed. The course will use the electronic information technology to teach basic knowledge, which can help students carry on the creation and practice with more time.

\section{REFERENCES}

[1] Duan Xingyuan, Fan Ying, Hu Xiuqin, "The Optimized Path and Practice on the Clothing Structure Design Teaching Toward Art school student",Journal of Jiangsu University of technology, vol.20,No 3,pp.109-113.June 2014.(In Chinese)

[2] Zhi Xiaolei, Zhang Wenbin, "Discussion of the Teaching Mode for "Dress Structure Design"," Teaching Archives, No. 182, pp. 100-101, June 2008. (In Chinese)

[3] Qin Jigang, "Clothing structure design is a creative thinking activity,'Journal of Donghua University(social science), vol. 12, No.4, pp.301-303,Dec, 2012. (In Chinese)

[4] Zhang Wenbin, Clothig Technology (clothing strcture design),Beijing:China Textile Press,2001,pp1. (In Chinese)

[5] Sun Shaorong, Introduction to higher education methods, revised edition, Shanghai: East China Normal University press, pp35,2010. (In Chinese)

[6] Sun Shaorong, Introduction to higher education methods, revised edition, Shanghai: East China Normal University press, pp36,2010. (In Chinese) 